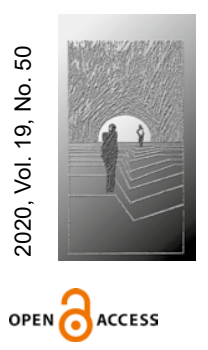

Hans-Georg Ziebertz

http://orcid.org/0000-0001-7750-0669

Universität Würzburg

Katholish-Theologische Fakultät

Institut für Praktische Theologie

hg.ziebertz@uni-wuerzburg.de

DOI: $10.35765 / \mathrm{hw} .1904$

\title{
Humanity on the Brink - Youth in Poland and Germany about Refugee Rights
}

\begin{abstract}
RESEARCH OBJECTIVE: The purpose of the presented paper, which has empirical nature, is to obtain data on how the rights of refugees are perceived today.
\end{abstract}

THE RESEARCH PROBLEM AND METHODS: The research problem of the paper is: How do youth in Germany and Poland evaluate refugee rights and what factors influence their attitude towards refugee rights? The survey method was used in the research. The data collection took place 2013/2014. In Germany, the survey included a total of 2157 students, in Poland 1211 respondents.

THE PROCESS OF ARGUMENTATION: The study was based on the assumption that attitudes towards refugee rights are predicted by such factors as: human dignity, empathy, religious beliefs, and socio-political perceptions and convictions. Based on these determinants, a conceptual model was created and used in the research.

RESEARCH RESULTS: The findings show that respondents differ regarding refugee rights. German youth show some support for refugee rights and Polish youth are ambivalent. The strongest predictor for support of refugee rights for both groups is the concept of multiculturalism. The capacity for empathy and an advocacy of a politically active Christianity are important predictors, but only for the German sample.

CONCLUSIONS, INNOVATIONS, AND RECOMMENDATIONS: The fact that religious beliefs have hardly positive impact on the support of refugee rights is a desideratum for religious education.

$\rightarrow$ KEYWORDS: YOUTH RESEARCH, MULTICULTURALISM, RELIGION, HUMAN DIGNITY, REFUGEES

This text poses the question of modern man's being in the world, his past and goals for the future and, and very decisively, his anchoring in humanity that finally affects all human beings. The question of humanity for all is a clear programme against egoism at the micro level and nationalism at the macro level. It has religious roots in the image of God of all human beings and in the commandment of charity. A special case of humanity 


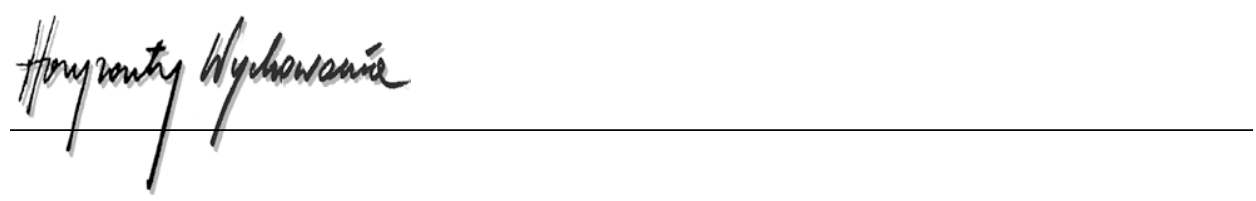

at this time is the handling of the many refugees who want to escape war or poverty and knock on Europe's door. In numerous international documents, countries have undertaken to protect people whose lives are at risk. So it is not just a question of morality, but of implementing international commitments, not to turn a blind eye to the enormous migratory movements around the world.

The question this paper addresses is: How do youth in Germany and Poland ${ }^{1}$ evaluate refugee rights and what factors influence their attitude towards refugee rights? This question should not be answered speculatively, but empirically. Note that empirical research into rights does not reflect on the legal status of rights per se, but on the legitimacy of these rights in people's perspective. The development of a human rights culture in a democratic society depends on the support of the people who make up that society. It is therefore important to know if citizens agree with the rights in question (in this case, refugee rights). The introduction to this paper explains the concepts used in this study, the second section discusses the research methodology, and the third section presents the findings of this research, followed by discussion.

\section{Introduction}

\section{Refugee rights}

The stranger is a protected person in the New Testament context. Matthew 25 is about the final judgement of God. In this judgement, we are told that God will separate people from each other as a shepherd separates the sheep from the goats $(25,32)$. Those who are blessed are characterized by several behaviours: "For I was hungry and you gave me food, I was thirsty and you gave me drink, I was a stranger and you welcomed me" $(25,35)$. Among all the behaviours that are highlighted as valuable in God's sight is an empathetic attitude towards strangers. However, this Christian ideal is currently causing (mostly Christian) Europeans major problems.

In article 12, the International Covenant of Civil and Political Rights (UN, ICCPR) states that "everyone lawfully within the territory of a State shall, within that territory, have the right to liberty of movement and freedom to choose his residence" and "everyone shall be free to leave any country, including his own." According to this line of reasoning, refugees must receive the same treatment as that accorded to aliens generally with regard to (among others) the right to choose their living place and to move freely within a country (UoM 2003). Given the masses of people that are currently pushing into Europe, these rights are now being put to the test, and this situation makes it imperative that people's attitudes towards refugees be examined. At the time this research project was initiated, the extent of the refugee inflow into Europe was unknown. Furthermore,

${ }^{1}$ I am grateful to Claudia Sarti (Nijmegen, NL), member of the international research group 'Religion and Human Rights', for allowing me the use of the Polish data for this comparative paper. 
the questions we wanted to answer were somewhat general. We wanted to explore how young people respond to claims that the government should guarantee political refugees' freedom to travel and provide them with a decent standard of living.

Since then, it is not an exaggeration to say that the treatment of refugees has become Europe's most pressing problem. Governments are in conflict with each other about which policy is appropriate. Within the nation-states themselves, right-wing populists are gaining increasing influence, precisely because they engage in polemics against immigration, and there is no doubt that Europe's policy regarding foreigners is in a state of crisis. Poland is a country that represents a strict position regarding the refusal to accept refugees. Germany, however, is a country that has taken a large number of refugees after Angela Merkel's "welcome-speech" in 2015. In the time of the great wave of refugee's host countries are barely prepared to accommodate the huge number of people. Even if the official policies in Poland and Germany differ considerably, in the civil society of both countries there is both support for the refugees, but also loud protests against the huge influx of refugees entering these countries.

First of all, it needs to be said that, in everyday language, both in the media and in political statements, the terms "economic migrant," "refugee" and "asylum seeker" are not used consistently. Economic migrants are people who leave their home country to look for better work and a higher standard of living. A refugee is someone who has a well-founded fear of being persecuted in his or her home country for reasons of race, religion, nationality, membership of a particular social group or political opinion - according to the Convention Relating to the Status of Refugees (UN 1951), with its additional protocol of 1967. A refugee, in fact, is outside the country of his or her nationality and is unable to avail himor herself of the protection of that country. An asylum seeker, on the other hand, has fled from his or her home country and is seeking refugee status in another country. An asylum seeker has to undergo a legal procedure to examine whether his or her fear of persecution is authentic and valid according to the law (UoM 2003). This often leads to a populist distinction being made between proper and non-proper refugees (Kneeborn, 2010).

Migration is a fact. Let us briefly look at four contexts that are able to shape attitudes towards refugees.

\section{Four concepts that can influence attitudes towards refugee rights}

\section{Human dignity}

Human dignity is a central concept found within the rationale of human rights discourses. Empirically, we can assume that other convictions will also influence attitudes towards refugee rights. All human rights treaties regard human dignity as an important concept for the understanding of human rights (cf. Bagaric \& Allen, 2006; McCrudden, 2014; Ziebertz et al., 2017). Since the 1948 Universal Declaration of Human Rights (UDHR), many declarations have referred to human dignity as a key concept for human rights or 


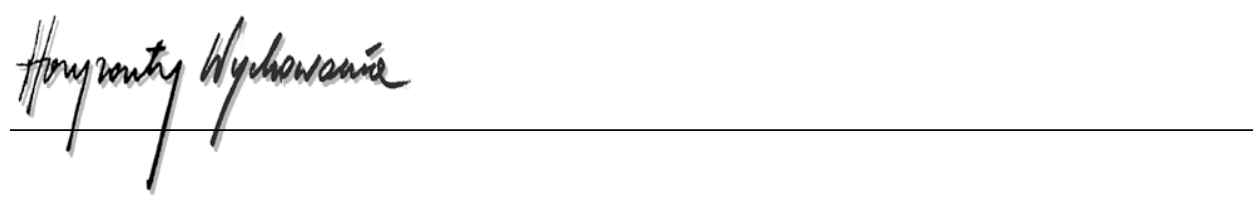

even their very foundation (cf. International Covenant on Economic, Social and Cultural Rights [ICESCR] 1966, and the Charter of Fundamental Rights in the European Union, 2000). The question is: is the concept of human dignity also empirically important in terms of attitudes towards refugee rights?

\section{Belief}

Conceptually, there is an important connection between the concept of human dignity and Christian belief via the concept of humankind being created in the likeness of God (Genesis 1:26-27). In Christian thought, Genesis serves as proof that human beings are special creations of God. It is therefore the responsibility of human beings to care for each other. Indeed, belief in God means loving God and loving my neighbour. Charity is therefore one of the basic values in Christian ethics, grounded in the value of the person. Christian belief has also a political dimension, and the role of the churches gives expression to this political dimension. Churches can show their commitment by public actions that defend the underprivileged. All these factors will be taken into account as possible predictors for people's attitudes towards refugee rights.

\section{Empathy}

As a dimension of personality, the ability to be empathic will also be included. In social psychology, empathy is defined as "the reactions of one individual to the observed experiences of another" (Davis, 1983, p. 113). Empathy is based on identification, that is, the awareness that the other has the same feelings and needs as me. Empathy leads to attentiveness and caring. In the context of this research, empathic people are likely to show a higher appreciation for refugee rights.

\section{Socio-political context}

Refugee rights concern the functioning of the political and social system in general. It can be assumed that the agreement or disagreement of refugee rights is not independent of society's perceptions and one's individual political orientation. This research includes the concept of a multicultural society: modern societies should create a context that enables people from different cultures to live together in peace. Refugees enlarge cultural diversity. Antagonists of multiculturalism stress that different cultures stimulate conflicts (cf. Albertazzi \& McDonnell, 2008). This issue will also be taken into account in this research: should the government be stricter in insisting on adherence to law and order, especially as far as foreigners are concerned? Is cultural pluralism a threat to the autochthon culture or does it symbolize cultural richness (Doise, Spini \& Clement, 1999)? Because the presence of a large number of refugees in a country causes controversy, the question arises: if and to what extent does the perception of socio-political events influence people's attitudes towards refugee rights? 


\section{Research methodology}

\section{Research procedure and sample}

The data collection took place 2013/14. In Germany, the survey was conducted in 11 (of 16) federal states and included a total of 2157 students in the age of about 17 (10th and 11 th grades). Of the participating students, $41 \%$ were male and $59 \%$ female. $71.6 \%$ of the respondents are Christians, 5.4\% Muslims and $20.4 \%$ describe themselves as non-religious students. The data collection in Poland took place in three geographical locations Olsztyn, Poznan and Warszawa. The sample includes 1211 respondents in the age of about 18 years. $60 \%$ of the respondents are female, $40 \%$ are male. $59 \%$ describe themselves as being Catholic, $12 \%$ as religious in a general sense and $25.4 \%$ as non-religious.

\section{Conceptual model}

This study is based on the assumption that attitudes towards refugee rights are predicted by certain factors. This is why the concept of human dignity, empathy, religious beliefs, and socio-political perceptions and convictions are included in this research. The question is: if and to what extent do these concepts predict youth's attitudes towards refugee rights? The conceptual model (fig. 1) lists all concepts.

\section{Conceptualization and operationalization}

All the concepts referred to in the conceptual model will be described in detail. When instruments are based on scales (instead of single items), we tolerate a Cronbach's alpha of minimum .60 (DeVellis, 2003). With a few exceptions, the answering scheme is based on a five-point scale: disagree strongly (1), disagree (2), not certain (3), agree (4) and agree strongly (5).

\section{Refugee rights}

Two specific rights about refugees have been selected (see tab. 1). Together, the two items build the scale "refugee rights" with a Cronbach's alpha of .70 for Germany and .76 for Poland. 


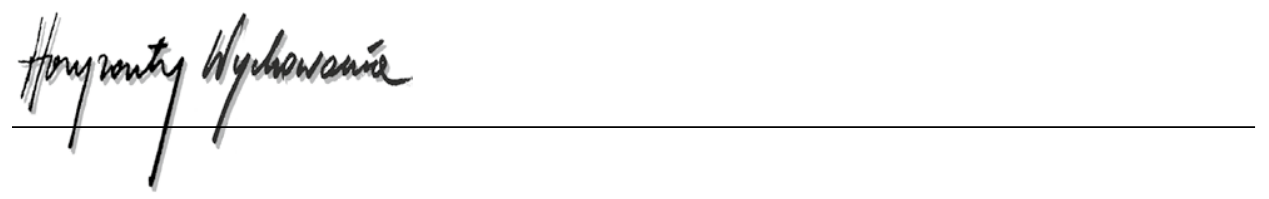

Figure 1. The conceptual model.

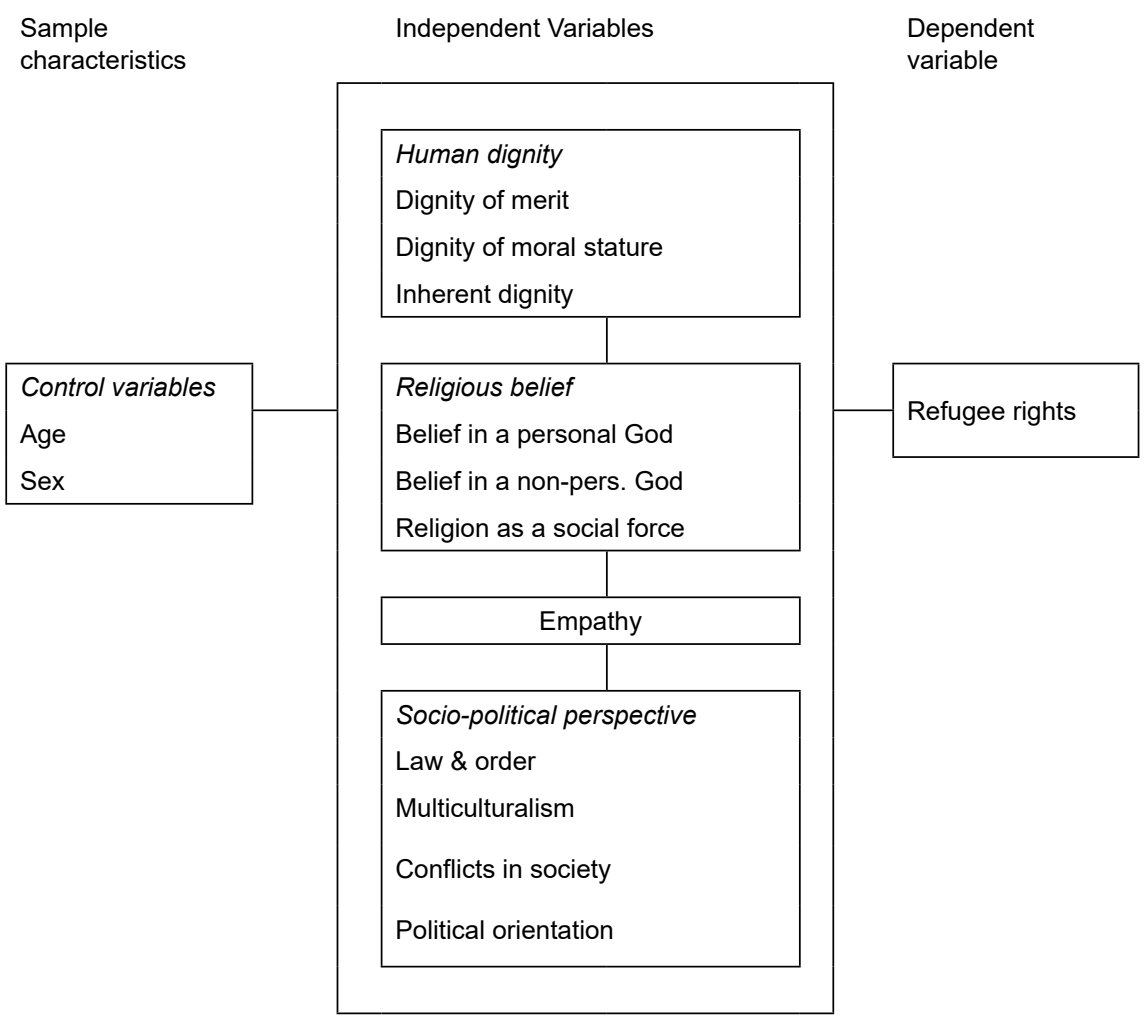

\section{Human dignity}

Human dignity consists of three different types of dignity: dignity of merit, moral dignity and inherent dignity (Nordenfelt, 2004). Merit was assessed using the following item: "The value of a person depends on the appreciation given to him or her by others." Moral dignity was assessed using the following statement: "The honour to be given to a person depends on his or her moral behaviour," and inherent dignity with "Each human being should be recognized just because he or she is a human being, irrespective of credit or moral behaviour."

\section{Religious belief}

The first topic concerns belief in God. One example of an item (six items) expressing a personal image of God (5 items) is: "I experience a personal bond between God and me." The non-personal image of God (five items) is measured - among others - with the 
following item: "I believe that there is a divine power out there." The Cronbach's alphas are .93 and .86. for Germany and .96 and .91 for Poland.

An example for items measuring the second topic, religion as a social force in society, is: "Religion should try to influence public opinion on social problems." The Cronbach's alpha is .67 for Germany and .71 for Poland.

\section{Empathy}

Empathy is measured by a scale developed by Davis (1983). Example: "I am often quite touched by things that I see happen." Four items build the scale "empathy" with a Cronbach's alpha of .66 for Germany and .71 for Poland.

\section{Socio-political perspective}

The first instrument to assess the socio-political perspective on society is the "RightWing Authoritarianism" scale (Altemeyer, 1998; Rattazzi et al., 2007). The four selected items measure the anxiety that "law and order" are not sufficiently guaranteed in contemporary society. Example: "What our country really needs instead of more 'civil rights' is much more law and order." The scale "law and order" has a Cronbach's alpha of .61 for Germany and .60 for Poland.

The second instrument concerns cultural diversity in a country (four items). An example is: "The variety of customs of people in this country is enriching." The Cronbach's alpha is .69 for Germany and .71 for Poland.

The third instrument focuses on several issues that can cause tension and conflicts in society. The items concerned included tension between "citizens and non-citizens," between "religions," "political preferences" and between different "ethnic groups." The Cronbach's alpha is .63 for Germany and .68 for Poland.

Finally, there was one item on respondents' political orientation from "left" to "right." Respondents could answer this question using a ten-point scale.

\section{Control variables}

Sex and age were included as control variables.

\section{Research questions and hypotheses}

The research questions guided the analysis of the empirical data. The first question concerns the descriptive analysis. What is the attitude of youth towards refugee rights in Germany and Poland and how do youth evaluate the other concepts used in this study? The second question is: how are these scales correlated? High significant correlations are indicators that these concepts might have an impact on attitudes towards refugee 


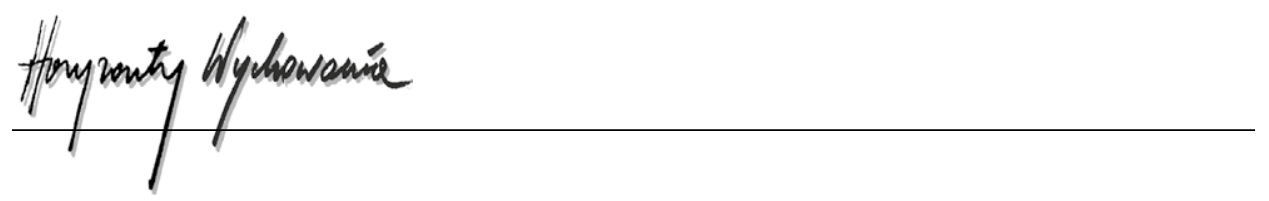

rights. The third question is whether and to what extent the selected potential predictors influence German and Polish youth's attitudes towards refugee rights.

This study is explorative because there is not enough knowledge available to elaborate strong hypotheses. We can ask whether predictors are strong or weak, whether their weight is equal or different, and if there is any hierarchy of influence among them, but we do not have strong arguments for the assumptions made in this research. Regarding the weight of the concept of human dignity in several covenants: will attitudes towards human dignity have an influence on attitudes towards refugee rights? Will other concepts have a greater explanatory power than dignity (e.g. belief in God)? Will the empirical analysis show that support for refugee rights is less among respondents who are conservative, who are critics of multiculturalism, and who perceive that the presence of foreigners leads to social conflict? To what extent do such students support refugee rights compared with those who are more leftist, who appreciate multiculturalism, and who do not perceive society as being subject to a high level of conflict (as a result of the presence of foreigners)?

\section{Empirical findings}

\section{Descriptive analyses}

Descriptive analysis of the dependent variable: refugee rights

The scale "refugee rights" consists of two items only (see tab. 1). German respondents evaluated these items slightly positively, Polish youth show an ambivalent habit. The disagreement (combination of the wo negative categories) with these rights among Germans is about $17-18 \%$, among Poles about $30 \%$. Controversially the agreement (the two positive categories) among Germans is $45-48 \%$ and among Poles $30-35 \%$. With a third of all respondents the undecided groups in both countries are quite equal. The standard deviations show that there is diversity in both groups. The mean of the entire scale is $M=3.37$ (SD 1.03) for Germany and $M=2.99$ (SD 1.09) for Poland. 
Table 1

Attitudes towards refugee rights (frequencies (\%), means and standard deviation

\begin{tabular}{|c|c|c|c|c|c|c|c|c|}
\hline Items & & $\begin{array}{l}\text { I totally } \\
\text { disagree }\end{array}$ & $\begin{array}{l}\text { I } \\
\text { dis-agree }\end{array}$ & $\begin{array}{l}\text { I'm not } \\
\text { sure }\end{array}$ & I agree & $\begin{array}{l}\text { I fully } \\
\text { agree }\end{array}$ & Mean & $S D$ \\
\hline $\begin{array}{l}\text { The government } \\
\text { should provide } \\
\text { a decent standard } \\
\text { of living for political } \\
\text { refugees. }\end{array}$ & $\begin{array}{l}\text { Germany } \\
\text { Poland }\end{array}$ & $\begin{array}{r}5.4 \\
16.0\end{array}$ & $\begin{array}{l}11.0 \\
14.6\end{array}$ & $\begin{array}{l}34.8 \\
33.8\end{array}$ & $\begin{array}{l}35.4 \\
27.8\end{array}$ & $\begin{array}{r}13.5 \\
7.3\end{array}$ & $\begin{array}{l}3.41 \\
2.96\end{array}$ & $\begin{array}{l}1.03 \\
1.17\end{array}$ \\
\hline $\begin{array}{l}\text { The government } \\
\text { should guarantee } \\
\text { political refugees } \\
\text { freedom to travel. }\end{array}$ & $\begin{array}{l}\text { Germany } \\
\text { Poland }\end{array}$ & $\begin{array}{r}5.3 \\
14.0\end{array}$ & $\begin{array}{l}13.9 \\
16,8\end{array}$ & $\begin{array}{l}36.6 \\
38.2\end{array}$ & $\begin{array}{l}31.1 \\
23.4\end{array}$ & $\begin{array}{r}13.1 \\
6.6\end{array}$ & $\begin{array}{l}3.33 \\
2.92\end{array}$ & $\begin{array}{l}1.04 \\
1.01\end{array}$ \\
\hline
\end{tabular}

\section{Descriptive analysis of the independent variables}

All items in table 2 used the answering scheme from 1 ("I totally disagree) to 5 ("I totally agree").

Regarding the concept of human dignity, the findings show an interesting difference between German and Polish youth. Firstly, the means of the three dimensions of human dignity show that inherent dignity obtained the highest acceptance $(M=3.77)$ within the German group, followed by dignity as moral behaviour $(M=3.34)$. Polish youth score highest on dignity as dependent on behaviour $(\mathrm{M}=3.55)$ and put the concept of inherent dignity on the second place $(M=3.26)$. Dignity of merit is rejected by respondents in both countries, particularly by Polish youth $(M=1.96)$; Germans $(M=2.26)$. Bearing in mind that the international discourse on human dignity shows a clear preference for dignity as being inherent to human beings, the answers of the young people who participated in this research project only partially mirror this view.

Secondly, religious belief is discussed. Obviously, all respondents value the three scales ambivalently or negatively. As far as German youth are concerned, belief in a personal God attracted the most rejection $(M=2.49)$, and belief in a non-personal God is ambivalent-negative $(M=2.81)$. The third concept about the role of a religion (church) as a social force, being active in public discourses on social issues and advocating for the poor and underprivileged, was evaluated ambivalently $(M=2.97)$ by young Germans. Compared with the images of God, the scale concerning the function of religion shows a low standard deviation, which means that the differences in the sample were small. Polish youth value both, the personal $(M=2.90)$ and non-personal image of God $(M=3.18)$ ambivalent and they reject a socio-political engagement of the church $(\mathrm{M}=2,63)$.

As far as empathy is concerned, the means of Germans $(M=3.65)$ and Polish youth $(M=3.66)$ are quite similar positive evaluated. The standard deviation in both cases is moderate. Respondents underpin the importance of empathy and the later question will be if this causes support for refugee rights. 


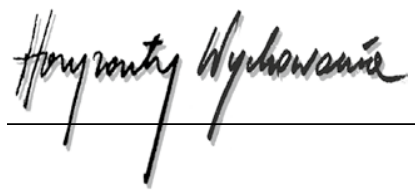

Fourthly, a group of items was included that related to the perception of socio-political issues in society. Students evaluated the law and order scale as ambivalent (Germany $M=3.01$; Poland $M=3.04$ ), with little diversity within both groups. The next scale is about the evaluation of cultural pluralism and multiculturalism. The attitude of German respondents towards multiculturalism is quite positive $(M=3.47)$, while Poles show an ambivalent-positive reaction $(M=3.19)$. Finally, German students perceive a certain degree of tension and conflict in society as a result of the presence of citizens and non-citizens, and as a result of ethnic and religious differences $(M=3.43)$; this is hardly true for the experience of Polish youth $(M=1.60)$. This could be explained by the social structure of Poland which is in fact less culturally pluralist compared to Western European countries.

Table 2

Means $(M)$ and standard deviation $(S D)$ of the independent variables

\begin{tabular}{lcccc}
\hline Scales & GER & GER & PL & PL \\
& M & SD & M & SD \\
\hline Human Dignity: merit & 2.26 & 1.10 & 1.96 & 1.14 \\
Human Dignity: moral behaviour & 3.34 & 1.05 & 3.55 & 1.03 \\
Human Dignity: inherent & 3.77 & 1.17 & 3.26 & 1.32 \\
Belief: Personal God & 2.49 & 1.14 & 2.90 & 1.25 \\
Belief: Non-personal God & 2.81 & 1.05 & 3.18 & 1.14 \\
Belief: Religion as a social force & 2.97 & .67 & 2.63 & .83 \\
Personality: Empathy & 3.65 & .80 & 3.66 & .77 \\
Politics: Law and order & 3.01 & .75 & 3.04 & .75 \\
Politics: Multiculturalism & 3.47 & .75 & 3.19 & .91 \\
Politics: Conflicts in society & 3.43 & .69 & 1.60 & .70 \\
\hline
\end{tabular}

Answering scheme: disagree strongly (1), disagree (2), not certain (3), agree (4) and agree strongly (5).

In addition to the socio-political items, students were asked how they see themselves politically on the continuum from left to right (see tab. 3). If we count categories 1-4 as leftist and $7-10$ as right-wing, we find $39.8 \%$ of German respondents and only $23.3 \%$ of Polish youth at the left. At the right end we find and $8.7 \%$ of the Germans but $36.6 \%$ of Polish respondents with right-wing sympathies. Politically both samples differ strongly. 
Table 3

Political orientation

In political matters, people talk of "the left" and "the right." How would you position your views on this scale?

\begin{tabular}{lcrrrrrrrrrc}
\hline Left & 1 & 2 & 3 & 4 & 5 & 6 & 7 & 8 & 9 & 10 & right \\
GER & 5.0 & 5.4 & 12.0 & 17.4 & 41.0 & 10.7 & 5.1 & 2.0 & 0.7 & 0.9 & $\%$ \\
PL & 3.3 & 4.0 & 7.4 & 8.6 & 26.4 & 13.7 & 11.3 & 12.9 & 5.1 & 7.3 & $\%$ \\
\hline
\end{tabular}

\section{Correlation between refugee rights and independent variables}

In order to answer the second research question, a correlation analysis was undertaken. The analysis in table 4 shows that, in the German group, there are 11 highly significant correlations between the refugee rights and all independent variables, in the Polish group there are five.

To begin with human dignity, dignity of merit and behaviour show only low correlation coefficients, which are negative in three cases. The interpretation is that both understandings of dignity and refugee rights are antagonistic. Inherent dignity shows a weak correlation for Germans and a medium correlation for Poles. The meaning is that respondents who support inherent dignity, also support refugee rights. This is even more valid for Poles than for Germans.

Three scales with religious content follow. Surprisingly, for Poles none of these concepts correlate with refugee rights. For them, belief is neither a positive nor a negative correlate to refugee rights. This is not the case for Germans. Although the personal and non-personal image of God shows only low positive correlations, the coefficient for religion as a social force quite is higher. Young Germans make a connection between belief and support for refugee rights. This is especially valid for respondents who wish the church active on the socio-political field.

Empathy was defined as the awareness of the other, attentiveness and caring. The expectation was that empathic people could support refugee rights more than less empathic ones. Germans as well as Poles see a positive high significant connection between empathy and refugee rights. The coefficient of Germans is considerably higher than the Polish one.

Four scales on politics follow. For Germans the "law and order" attitude correlates negatively with refugee rights, while for Poles there is no correlation. Multiculturalism show the highest correlations in both subsamples $(r=.431 ; r=.530)$. The correlations are positive which means that openness for cultural diversity goes together with a positive attitude towards refugee rights. The perception of conflicts in society does not matter in Poland and shows only a low negative correlation for Germany. The negative sign means that the more conflicts are absent the more refugee rights are supported. Finally, political orientation counts. For both subsamples the sign is negative which indicates that the leftist students are, the more they support refugee rights. 


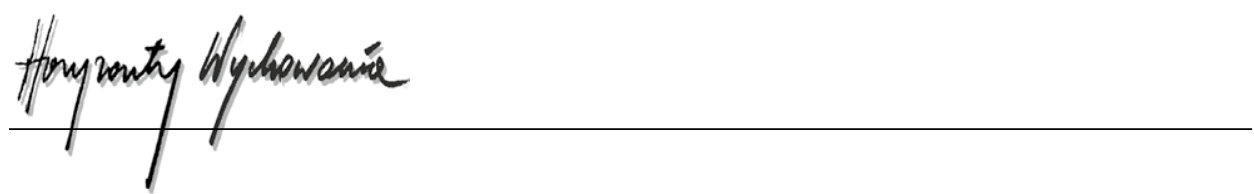

With age and sex two population characteristics have been included. The coefficients show into the same direction but differ in strength. Regarding age the finding is that younger respondents are the more they agree with refugee rights. Also male and female differ: refugee rights are more supported by women than by men. The correlation for Poles is twice as high as for Germans.

It is in the logic of correlation analysis that the relation is never one-way but always vice versa. In both samples, the correlation between attitudes towards refugee rights and multiculturalism is highest, followed by empathy, political orientation and inherent dignity. It can be assumed that these concepts will be found to be the most relevant predictors as far as attitudes towards refugee rights are concerned.

Table 4

Correlation of refugee rights and independent variables

\begin{tabular}{lcc} 
& \multicolumn{2}{c}{ Refugee rights } \\
\hline Dignity: merit & Germany & Poland \\
Dignity: behaviour & $-.079^{* * *}$ & $-.074^{*}$ \\
Dignity: inherent & $.045^{*}$ & $-.072^{*}$ \\
God: personal & $.171^{* * *}$ & $.240^{* * *}$ \\
God: non-personal & $.084^{* * *}$ & $\mathrm{Ns}$ \\
Religion: social force & $.081^{* * *}$ & $\mathrm{Ns}$ \\
Empathy & $.163^{* * *}$ & $\mathrm{Ns}$ \\
Law and order & $.282^{* * *}$ & $.180^{* * *}$ \\
Multiculturalism & $-.157^{* * *}$ & $\mathrm{Ns}$ \\
Conflicts & $.431^{* * *}$ & $.530^{* * *}$ \\
Political orientation & $-.058^{* *}$ & $\mathrm{Ns}$ \\
Age & $-.231^{* * *}$ & $-.258^{* * *}$ \\
Sex & $-.104^{* * *}$ & $-.098^{* *}$ \\
\hline
\end{tabular}

Note: ${ }^{*}, p<.05 ;{ }^{* *}, p<.01,{ }^{* * *}, p<.001$

\section{Predictors of attitudes towards refugee rights (regression analysis)}

In the case of the third research question, the predictors of attitudes towards refugee rights enter the picture. Table 5 shows the result of a hierarchical regression analysis for German and Polish youth. The explained variance is $25.5 \%$ for Germany and $31.6 \%$ for Poland. In both groups, the acceptance of an open and pluralist society is the strongest 
predictor for the support of refugee rights. Young people, who desire a culturally multifaceted society can also imagine to welcome and integrate refugees. One can say that it is above all the model of society that counts as predictor for refugee rights. This is even stronger valid for Poles $(\beta=.467)$ than for Germans $(\beta=327)$.

Regarding other predictor concepts the analyses between both countries differ. Most obvious is that for Germans there are more concepts of significant importance than for Poles. The second highest Beta $(\beta)$ for Poles is the agreement with the concept of inherent dignity, but the value is much lower $(\beta=.093)$. The meaning is who agrees that dignity is inherent to humans tends to be more open for refugees. Third the political opinion counts $(\beta=-.080)$, the leftist respondents are, the more the support refugee rights. Finally, younger students and females support refugee rights stronger than older students and males. It is surprising that none of the religious concepts count.

For the German sample there are more influential concepts, which are named in turn according to their explanatory weight. After multiculturalism first empathy is to be named: students who can identify with the struggles of others defend refugee rights $(\beta=.108)$. Empathy is followed by the appreciation of religion that acts as a social force in society $(\beta=.093)$. Belief in God has no impact. For Germans the authoritarian "law and order" attitudes come into play with a negative sign. The more students reject authoritarianism and the rule of law and order, the more they support refugee rights. As for Poles, also leftist young Germans support refugee rights. Finally, again like Poles, the younger German students are the more they stand up for refugees. With low significance sex has to me mentioned. Male Germans' attitude on refugees is slightly more positive than the females' one. 


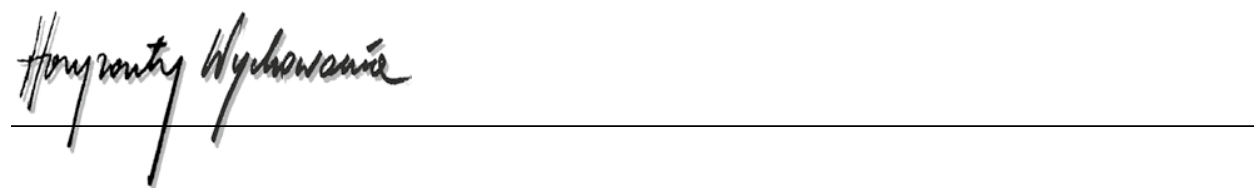

Table 5

The influence of human dignity, religious belief, empathy, socio-political perception and socio-demographic characteristics on attitudes towards refugee rights (Hierarchical regression)

\begin{tabular}{|c|c|c|}
\hline & Germany & Poland \\
\hline \multicolumn{3}{|l|}{ Human dignity } \\
\hline Merit & Ns & Ns \\
\hline Behaviour & Ns & Ns \\
\hline Inherent & $.093^{* * *}$ & $.093^{* * *}$ \\
\hline \multicolumn{3}{|l|}{ Religious belief } \\
\hline Belief in personal God & Ns & Ns \\
\hline Belief in non-personal God & Ns & Ns \\
\hline Religion as social force & $.108^{* * *}$ & Ns \\
\hline \multicolumn{3}{|l|}{ Value } \\
\hline Empathy & $.173^{* * *}$ & Ns \\
\hline \multicolumn{3}{|l|}{ Socio-political perception } \\
\hline Law and order & $-.088^{* * *}$ & Ns \\
\hline Multiculturalism & $.327^{* * *}$ & $.467^{* * *}$ \\
\hline Conflicts in society & Ns & Ns \\
\hline Political orientation & $-.078^{\star * \star}$ & $-.080^{\star *}$ \\
\hline \multicolumn{3}{|l|}{ Socio-demographic } \\
\hline Age & $-.073^{\star \star \star}$ & $-.050^{*}$ \\
\hline Sex & $.043^{*}$ & $-.064^{*}$ \\
\hline $\mathrm{R}^{2}$ & $25.5 \%$ & $31.6 \%$ \\
\hline Change in $\mathrm{F}$ & $6.372^{* *}$ & $39.048^{* * *}$ \\
\hline
\end{tabular}

\section{Discussion}

This edition of Horizons highlights the globalization of the world and its consequences for individual, social and political life. A striking aspect of globalization is the worldwide migration. Empirically many countries in the world are currently undergoing major changes 
through migration. Irrespective of what causes migration, almost all societies around the globe became multinational and polyethnic. The world currently comprises about 180 independent states, but there are 600 living languages, and on average 3.3 languages per country. Further, there are 5,000 ethnic groups, about 28 groups per nation-state on average (Blanks in reference to Kymlicka 1995, p. 1). These numbers underline the improbability that a state could permanently immunise itself against polyphony. Nevertheless, states have different policies on migration issues, of which Germany and Poland are good examples. With the slogan "my country first," social balance and humanity threaten to fall by the wayside. Dealing with refugees in Europe is a sad example of this.

In this article we have looked at young people in Poland and Germany and examined how they think about refugee rights. The empirical findings in this research show that Polish youth are ambivalent, while German youth are slightly positive in their support of refugee rights. They probably mirror the cultural climate of their home countries. The perception of society is the most influential factor on attitudes towards refugee rights in both groups. Students' preference for a pluralist and multicultural society is the best explanatory factor for their support of refugee rights. Students appreciate cultural diversity and experience the plurality of lifestyles and cultures as enriching, insofar as the large number of refugees is not experienced as dangerous for social cohesion. Students who think so are more left than right when in doubt. In this case, there is no difference between German and Polish youth.

In addition to having an open-minded perspective on society, a personal factor comes into the picture, almost for German respondents. This is the ability to identify oneself with the suffering of others. Within the German group of participants, this ability is the second strongest predictor for a positive attitude towards refugee rights.

Germans and Poles are aware of the concept of inherent human dignity and they connect it, positively, with refugee rights. This concept is quoted in most international human rights treaties as well as in the European Charter of Fundamental Rights; it is also the first article in the German constitution (Grundgesetz).

What is surprising in this research is the finding for religion. German youth focuses on the institutional character of religion. A church that acts as a social force in society is seen as a companion for the support of refugee rights. Individual belief does not count. For Polish youth, however, none of these concepts count at all. It is surprising because Christian religion gives in its teaching many arguments kindness towards the strangers. Students do not develop ethical responsibility from religion to refugee rights.

We have to keep in mind that political concepts show the strongest support for refugee rights. To help increase the support of refugee rights, actors in society have to argue that a pluralist society is the best model of harmonious life in a global world. They also have to argue against the many populist movements for whom foreigners are regarded as the biggest danger in society. Furthermore, actors in society and education can stimulate personal qualities, such as empathy and compassion, to give a foundation to the support of refugee rights. The results regarding religion and belief should be serious food for thought for both churches and religious education, for the 


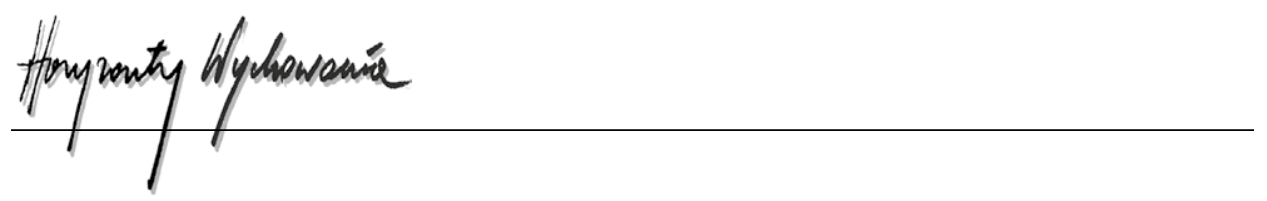

fact remains that, significantly, religious belief has only a low impact on the support of refugee rights.

\section{BIBLIOGRAPHY}

Albertazzi, D. \& McDonnell, D. (2008). Twenty-First Century Populism: The Spectre of Western European Democracy. New York and London: Palgrave Macmillan.

Altemeyer, B. \& Hunsberger, B. (1992). Authoritarianism, Religious Fundamentalism, Quest, and Prejudice. International Journal for the Psychology of Religion, 2:2, 113-133.

Bagaric, M. \& Allen, J. (2006). The Vacuous concept of Dignity. Journal of Human Rights, 5, 257-270.

Banks, J.A. (2008). Diversity, Group Identity, and Citizenship Education in a Global Age. Educational Researcher, 37, 3, 129-139.

Davis, M.H. (1983). Measuring individual differences in empathy: Evidence for a multidimensional approach. Journal of Personality and Social Psychology, 44, 113-126.

DeVellis, R.F. (2003). Scale development: Theory and applications. London: Sage.

Doise, W. Spini, D., \& Clémence, A. (1999). Human rights studied as social representations in a cross-national context. European Journal of Social Psychology, 29, 1-29.

Kneeborn, S. (2010). Refugees and displaced persons: the refugee definition and 'humanitarian' protection. In: S. Joseph \& A. McBeth (eds.), Research Handbook on International Human Rights Law. Cheltenham/Northampton: Edward Elgar, 215-240.

Kymlicka, W. (1995). Multicultural Citizenship: A liberal theory of minority rights. New York: Oxford University Press.

McCrudden, Chr. Ph. (2014). Understanding Human Dignity. Oxford: Oxford University Press.

Nordenfelt, M.N.L. (2004). The Varieties of Dignity. Health Care Analysis, 12, 2, 69-89.

Rattazzi, A.M.M., Bobbio, A. \& Canova, L. (2007). A short version of the Right-Wing Authoritarianism (RWA) Scale. Personality and Individual Differences, 43: 5, 1223-1234.

UoM (2003). University of Minnesota Human Rights Center. Study Guide: The Rights of Refugees. Retrieved from: http://www1.umn.edu/humanrts/edumat/studyguides/refugees.htm

Ziebertz, H.-G., Döhnert, S., \& Unser, A. (2017). Predictors of attitudes towards human dignity: an empirical analysis among youth in Germany. In: H.-G. Ziebertz \& C. Sterkens (eds.), Civil human rights, human dignity and religion: empirical research and theoretical reflections. Dordrecht: Springer.

\section{Documents}

Convention relating to the Status of Refugees, 1951, with its additional protocol of 1967 (UN). International Covenant on Civil and Political Rights, 1966 (UN).

International Covenant on Economic, Social and Cultural Rights, 1966 (UN).

Convention on the Participation of Foreigners in Public Life at Local Level, CoE, Strasbourg, 5.II.1992.

Charter of Fundamental Rights in the European Union, 2000.

\section{Copyright and License}

This article is published under the terms of the Creative Commons Attribution - NoDerivs (CC BY- ND 4.0) License http://creativecommons.org/licenses/by-nd/4.0/ 